\title{
Correlation of apoptosis with tumour cell differentiation, progression, and HPV infection in cervical carcinoma
}

\author{
Y Shoji, M Saegusa, Y Takano, M Ohbu, I Okayasu
}

\begin{abstract}
Aims-To clarify the significance of apoptosis in the progression of uterine cervical neoplasias, including cervical intraepithelial neoplasia (CIN), microinvasive carcinoma (MIC), and invasive squamous cell carcinoma (ISCC) categories, in relation to cell proliferation and human papilloma virus (HPV) infection.

Methods-Forty six cases of CIN I/II, 75 of CIN III, 16 of MIC, and 44 of ISCC were examined using formalin fixed and paraffin wax embedded samples. The $T d T$ mediated dUTP-biotin nick end labelling (TUNEL) method for detection of apoptotic cells was performed along with $\mathrm{Ki}-67 \mathrm{im}$ munohistochemistry. Presence of HPVDNA was confirmed by PCR-RFLP assay. Results-Apoptotic labelling indices, calculated after counting positive nuclei among at least 2000 nuclei, showed significant positive correlation with histological malignant grading in CIN and tumour cell invasion into stroma. In contrast, similar Ki-67 labelling index values were found in CIN, MIC, and ISCC. Although HPV-DNA was detected in 35/46 CIN I/II (76.1\%), 53/74CIN III (71.6\%), 9/ 16 MIC (56.3\%), and 36/44 ISCC (81.8\%), there was no apparent relation with the apoptotic labelling indices.

Conclusions-Apoptosis in cervical neoplasias may be closely related to tumour cell differentiation and progression. It also seems unlikely that HPV itself is directly related to pathways regulating apoptosis. (f Clin Pathol 1996;49:134-138)
\end{abstract}

Keywords: apoptosis, HPV, CIN, SCC, Ki-67

Although a relation between genesis of cervical carcinomas and human papillomavirus (HPV) infection has been considered, it is widely accepted that HPV infection alone is not responsible for cervical neoplasia, and several cofactors, such as other infectious agents, genetic abnormalities, and smoking have been identified from epidemiological and experimental investigations. ${ }^{1}$ The fact that spontaneous regression frequently occurs in cervical intraepithelial neoplasia (CIN) type I or II lesions but a part of CIN III progresses to invasive carcinoma ${ }^{23}$ suggests that selection of a cell population with high malignant potential may be closely linked to progression of cervical neoplasias.
The rate of cell accumulation is determined by the balance of cell proliferation and death. Apoptosis (programmed cell death) is an important mechanism of cell loss in tissue modelling for vertebrate development, with apparent differences from necrosis. ${ }^{4}$ For example, apoptotic cells are not associated with an inflammatory reaction, even when present in large number. ${ }^{5}$ Regulation of the process leading to death involves expression of several oncogenes or oncosuppressor genes, such as c-myc, ${ }^{6}$ p53, ${ }^{7}$ and $b c l-2 .{ }^{8}$ Recently, the significance of apoptosis in development or growth of human malignant tumours has become a major topic of discussion, particularly in relation to cancer treatment by irradiation and anticancer drugs. ${ }^{9}$

The TdT mediated dUTP-biotin nick end labelling (TUNEL) method developed by Gavrieli et $a l^{10}$ is able to detect apoptosis at the single cell level. In the present study, we assessed the significance of apoptosis for progression of cervical neoplasias-including CIN, microinvasive carcinoma (MIC), and invasive squamous cell carcinoma (ISCC) - by this approach, as well as using $\mathrm{Ki}-67$ immunohistochemistry to estimate cell proliferation. In addition, the relation between apoptosis and HPV infection was also examined using a polymerase chain reaction (PCR) assay for detection of HPV-DNA.

\section{Methods}

CASE SELECTION

A total of 181 cases was selected from the surgical patient's files of Kitasato University Hospital. Tissue slices had been fixed in 10\% formalin and embedded in paraffin wax. Histological examination was mainly performed according to Richart's criteria ${ }^{11}$; thus cervical intraepithelial neoplasia (CIN) I encompasses mild dysplasia, CIN II, moderate dysplasia, and CIN III, severe dysplasia and carcinoma in situ (CIS). The cases investigated were divided into 46 cases of CIN I and II, 75 cases of CIN III, 16 cases of MIC, and 44 cases of ISCC.

TUNEL ASSAY

TUNEL procedure was performed according to the description of Gavrieli et al, ${ }^{10}$ with minor modification. Briefly, after routine deparaffinisation and treatment with $0.3 \%$ hydrogen peroxidate $\left(\mathrm{H}_{2} \mathrm{O}_{2}\right)$, sections were digested with $100 \mu \mathrm{g} / \mathrm{ml}$ proteinase $\mathrm{K}$ (Merck) at room temperature for 15 minutes and washed with distilled water. Sections were immersed in TDT 

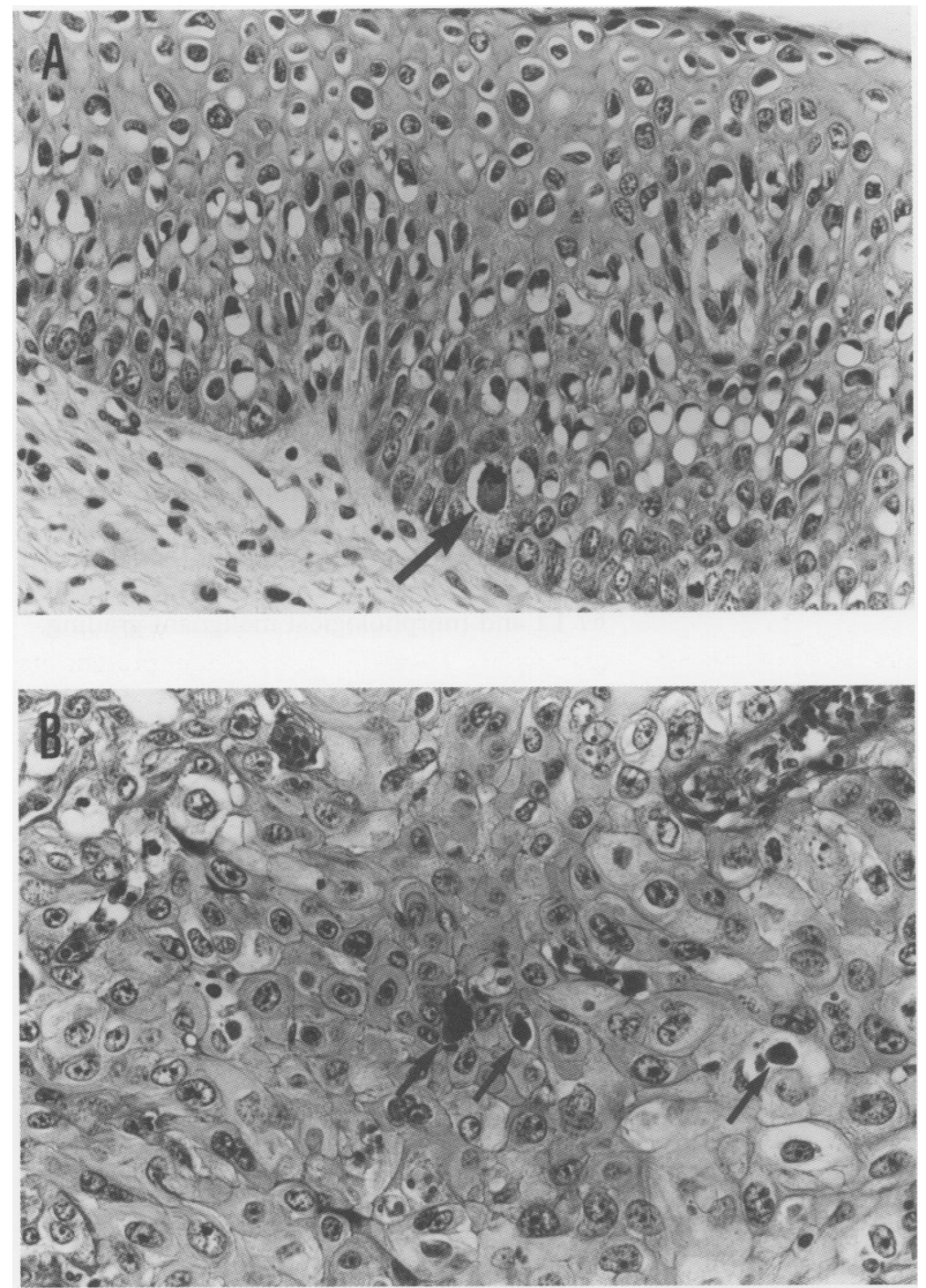

Figure 1 Note apoptotic cells (indicated by arrows) showing condensation of nuclear chromatin and loss of cell-cell contacts in haematoxylin-eosin sections. (A) CIN II, $\times 345$; (B) ISCC, $\times 345$.

\section{IMMUNOHISTOCHEMISTRY}

$\mathrm{Ki}-67$ immunoreactivity was detected by a combination of microwave oven heating and the standard Streptavidin-biotin-peroxidase complex method (Histofine SAB-PO (M) kit, Nichirei $\mathrm{Co})$, using rabbit anti-human $\mathrm{Ki}-67$ antigen ( $\times 300$ dilution, Dako).

\section{DNA EXTRACTION AND POLYMERASE CHAIN} REACTION (PCR) ASSAY

For detection of HPV-DNA, DNA samples were extracted from several serial $10 \mu \mathrm{m}$ thick paraffin wax sections, through phenol/chloroform treatment as described previously. The quality of the DNAs extracted was confirmed with $\beta$ globin gene specific primers which was able to amplify the 355 base pair fragment. ${ }^{12}$

The PCR assay was performed using the consensus primers for HPV L1 region, $\mathrm{L} 1 \mathrm{C} 1$ and $\mathrm{L} 1 \mathrm{C} 2$, which is able to detect $0.001 \mathrm{pg}$ of DNA of HPV types $6,11,16,18,31,33$, and 52 , and $0 \cdot 1 \mathrm{pg}$ of those of HPV types 42 and 58. ${ }^{13}$ Ten microlitres of PCR mixture containing $10 \mathrm{ng}$ template DNA, $1 \mu \mathrm{M}$ of each primer, and 0.5 unit Taq DNA polymerase (Takara) were prepared, and samples were amplified through 45 cycles. PCR was carried out as a replicate or triplicate assay and water instead of DNAs was used as a negative control.

HPV subtyping was determined by the restriction fragment length polymorphism (RFLP) assay with Rsa I, Dde I, and Hae III.

APOPTOTIC AND KI-67 LABELLING INDICES

The slide was randomly moved and five fields were selected for each case using a $\times 40$ objective and $\times 10$ ocular. All TUNEL signal positive or $\mathrm{Ki}-67$ immunolabelling nuclei from among at least 2000 tumour cells were then counted. In CIN lesions, these counting procedures were performed in the whole epithelial layers. Apoptotic and $\mathrm{Ki}-67$ labelling indices (A-LI and $\mathrm{Ki}-67 \mathrm{LI}$ ) were calculated as number per 100 cells.

buffer $(30 \mathrm{mM}$ Tris- $\mathrm{HCl}, \mathrm{pH} 7 \cdot 2,140 \mathrm{~m}$ sodium cacodylate, $1 \mathrm{mM}$ cobalt chloride) at roomtemperature for 10 minutes, and then incubated with $0.5 \mathrm{unit} / \mu \mathrm{l}$ terminal deoxynucleotidyl transferase (Boehringer Mannheim/ Yamanouchi) and $0.01 \mathrm{nmol} / \mu \mathrm{l}$ biotinylated11-dUTP (Sigma) in TDT buffer at $37^{\circ} \mathrm{C}$ for 60 minutes. Sections were rinsed with distilled water and the routine avidin-biotin-peroxidase complex method (Vecstastain ABC kit, Vector Laboratories) was used for detection of apoptotic signals.

Table 1 Correlation between malignant grading and apoptotic and $\mathrm{Ki}-67$ labelling indices. Values are means (SD)

\begin{tabular}{lll}
\hline & Apoptotic LI & Ki-67 LI \\
\hline CIN I/II (n=46) & $0 \cdot 26(0 \cdot 56)^{\mathrm{a}}$ & $47 \cdot 20(14 \cdot 45)$ \\
CIN III $(\mathrm{n}=74)$ & $0.82(1 \cdot 43)^{\mathrm{a}, \mathrm{b}}$ & $46.67(15 \cdot 97)$ \\
MIC $(\mathrm{n}=16)$ & $1.81(1.58)^{\mathrm{b}, \mathrm{c}}$ & $43.32(13 \cdot 81)$ \\
ISCC $(\mathrm{n}=44)$ & $4.65(2.95)^{\mathrm{c}}$ & $49.31(14 \cdot 00)$ \\
\hline
\end{tabular}

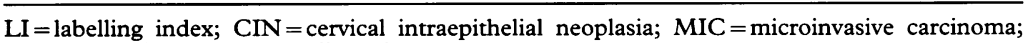
ISCC = invasive squamous cell carcinoma.

$\mathrm{a}_{\mathrm{a}, \mathrm{b}} \mathrm{p}<0 \cdot 005$.

${ }^{c} \mathrm{p}<0.001$.

\section{STATISTICS}

Values are given as mean (SD). Statistical analysis was performed using the Student $t$ test.

\section{Results}

APOPTOSIS IN CERVICAL NEOPLASIAS

Cells undergoing apoptosis showed condensation of nuclear chromatin, nuclear fragments (apoptotic bodies), and loss of cell-cell contacts in conventionally haematoxylin-eosin ( $\mathrm{H}$ and $\mathrm{E}$ ) sections (fig 1). These changes were sometimes not associated with necrotic or inflammatory foci.

TUNEL signals were detected not only in these cells but also in morphologically viable cells at the start of apoptosis, as identified by distinct nuclear staining. Positive cells were sporadically found in CIN and appeared in clusters in ISCC (fig 2). However, comparative observation of $\mathrm{H}$ and $\mathrm{E}$ stained serial sections 

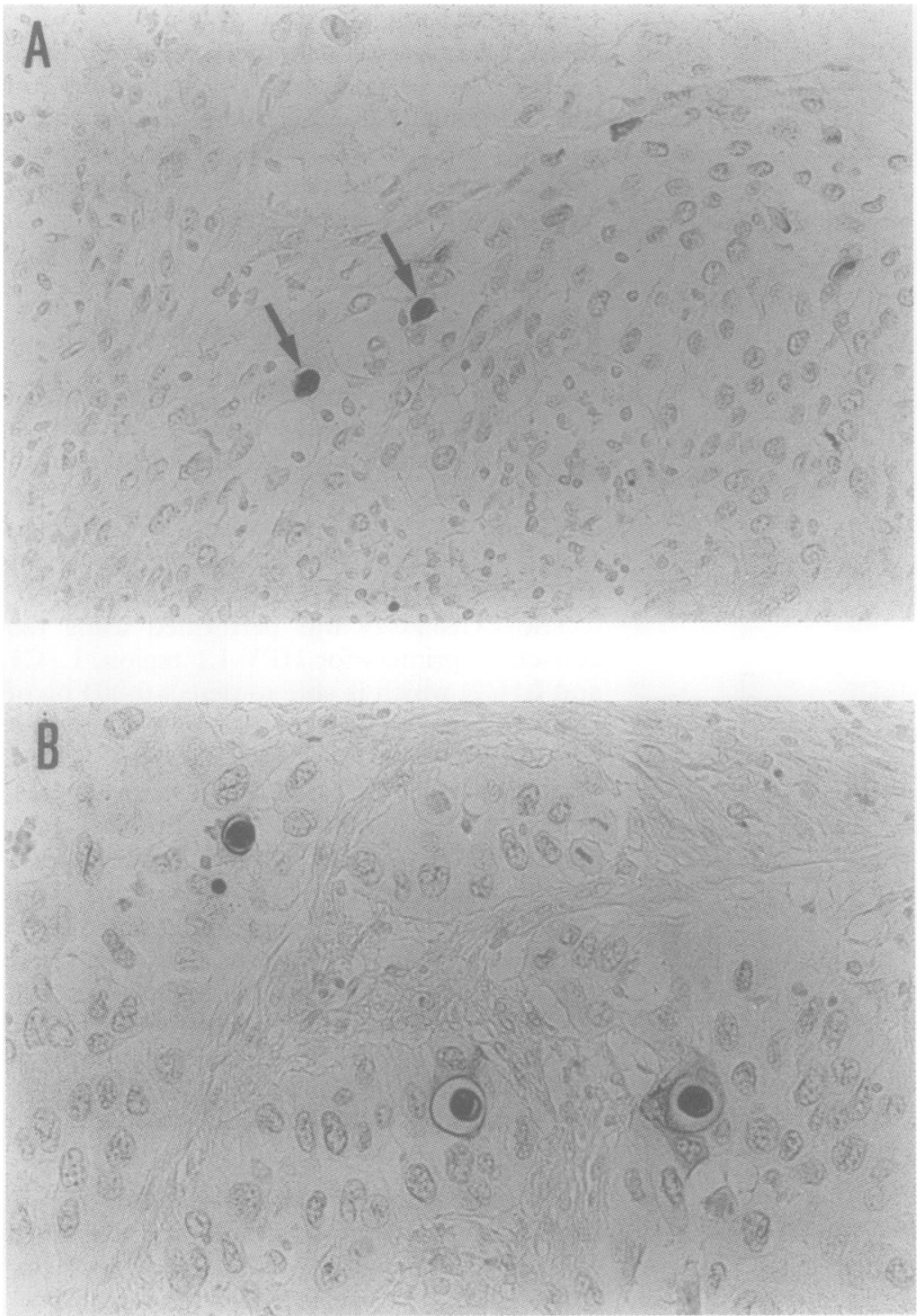

Figure 2 Cells undergoing apoptosis (indicated by arrows) show a distinct positive nuclear staining by the TUNEL method. (A) CIN II, $\times 345$; (B) ISCC, $\times 345$.

was necessary for verification, as non-specific staining of necrotic foci and inflammatory cells was evident. In addition, a few cells located at the most superficial layer of the normal cervical epithelia (edge of sections) were occasionally showed not only nuclear but not cytoplasmic staining, and it was difficult to determine whether these signals were specific or nonspecific.
Data on the correlation between apoptosis and histopathological grading of cervical neoplasias are summarised in table 1 . The A-LI clearly increased together with tumour progression, this being statistically significant.

\section{CELL PROLIFERATIVE ACTIVITY IN CERVICAL} NEOPLASIAS

In $\mathrm{CIN}, \mathrm{Ki}-67$ immunoreactivity was predominantly found in basaloid cells (basal and parabasal cells). Koilocytotic cells in the upper layers also occasionally showed positive staining. A heterogeneous distribution of $\mathrm{Ki}-67$ labelling cells within individual ISCC was noted (fig 3).

As evident from the results in tables 1 and 2 , there was no clear correlation between $\mathrm{Ki}$ $67 \mathrm{LI}$ and morphological malignant grading.

\section{RELATION BETWEEN APOPTOSIS AND HPV} INFECTION

With consensus primers for the HPV L1 region, amplified PCR products (approximately 260 base pairs (bp)) were detected, as shown in fig 4. HPV types were determined by RFLP analysis. For example, the PCR product originating from HPV 16 was cleaved into 169 bp and 84 bp fragments by Dde I digestion and was not digested by Rsa I.

PCR and RFLP analysis revealed HPV-DNA in $35 / 46 \mathrm{CIN} \mathrm{I/II}(76 \cdot 1 \%), 53 / 74 \mathrm{CIN}$ III $(71 \cdot 6 \%), 9 / 16 \mathrm{MIC}(56 \cdot 3 \%)$, and $36 / 44$ ISCC $(81 \cdot 8 \%)$. Of the HPV-DNA positive cases, HPV $16 / 18$ was found in $28(80 \%)$ in CIN I/ II, $38(71.7 \%)$ in CIN III, eight $(88.9 \%)$ in MIC, and $31(86 \cdot 1 \%)$ ISCC.

No apparent relation between A-LI and the presence of HPV-DNA could be demonstrated (table 2).

\section{Discussion}

The TUNEL technique is based on the specific binding of TdT to $3^{\prime}-\mathrm{OH}$ of DNA fragments in apoptotic nuclei, permitting the in situ visualisation of apoptotic cells. ${ }^{10}$ However, it is necessary to be careful when evaluating results as necrotic cells and some inflammatory cells, including neutrophils and lymphocytes, are also stained.

Table 2 Correlation between HPV infection and apoptotic and Ki-67 labelling indices. Values are means (SD)

\begin{tabular}{|c|c|c|c|c|}
\hline & \multicolumn{2}{|l|}{ Apoptotic LI } & \multicolumn{2}{|l|}{$K i-67 L I$} \\
\hline & $H P V(+)$ & $H P V(-)$ & $H P V(+)$ & $H P V(-)$ \\
\hline $\mathrm{CIN} \mathrm{I/II}$ & $\begin{array}{l}0.20(0.43)^{\mathrm{a}} \\
(\mathrm{n}=35)\end{array}$ & $\begin{array}{l}0.45(0 \cdot 85) \\
(\mathrm{n}=11)\end{array}$ & $\begin{array}{l}49 \cdot 51(14 \cdot 59) \\
(\mathrm{n}=35)\end{array}$ & $\begin{array}{l}39 \cdot 86(11 \cdot 74) \\
(n=11)\end{array}$ \\
\hline CIN III & $\begin{array}{l}0.98(1.62)^{\mathrm{a}, \mathrm{b}} \\
(\mathrm{n}=53)\end{array}$ & $\begin{array}{l}0.41(0.67) \\
(\mathrm{n}=21)\end{array}$ & $\begin{array}{l}48 \cdot 21(15 \cdot 37) \\
(n=53)\end{array}$ & $\begin{array}{l}43 \cdot 11(17 \cdot 10 \\
(\mathrm{n}=21)\end{array}$ \\
\hline MIC & $\begin{array}{l}2 \cdot 20(1 \cdot 84)^{\mathrm{b}, \mathrm{c}} \\
(\mathrm{n}=9)\end{array}$ & $\begin{array}{l}1 \cdot 31(1 \cdot 09) \\
(\mathrm{n}=7)\end{array}$ & $\begin{array}{l}41 \cdot 14(12 \cdot 8) \\
(\mathrm{n}=9)\end{array}$ & $\begin{array}{l}46 \cdot 11(15 \cdot 54) \\
(n=7)\end{array}$ \\
\hline ISCC & $\begin{array}{l}5 \cdot 15(2 \cdot 92)^{\mathrm{c}, \mathrm{d}} \\
(\mathrm{n}=36)\end{array}$ & $\begin{array}{l}2 \cdot 39(1.97)^{d} \\
(n=8)\end{array}$ & $\begin{array}{l}47 \cdot 46(13 \cdot 65) \\
(\mathrm{n}=36)\end{array}$ & $\begin{array}{l}57 \cdot 39(13.43) \\
(n=8)\end{array}$ \\
\hline
\end{tabular}

$\mathrm{LI}=$ labelling index; $\mathrm{CIN}=$ cervical intraepithelial neoplasia; $\mathrm{MIC}=$ microinvasive carcinoma; $\mathrm{ISCC}=$ invasive squamous cell carcinoma. 

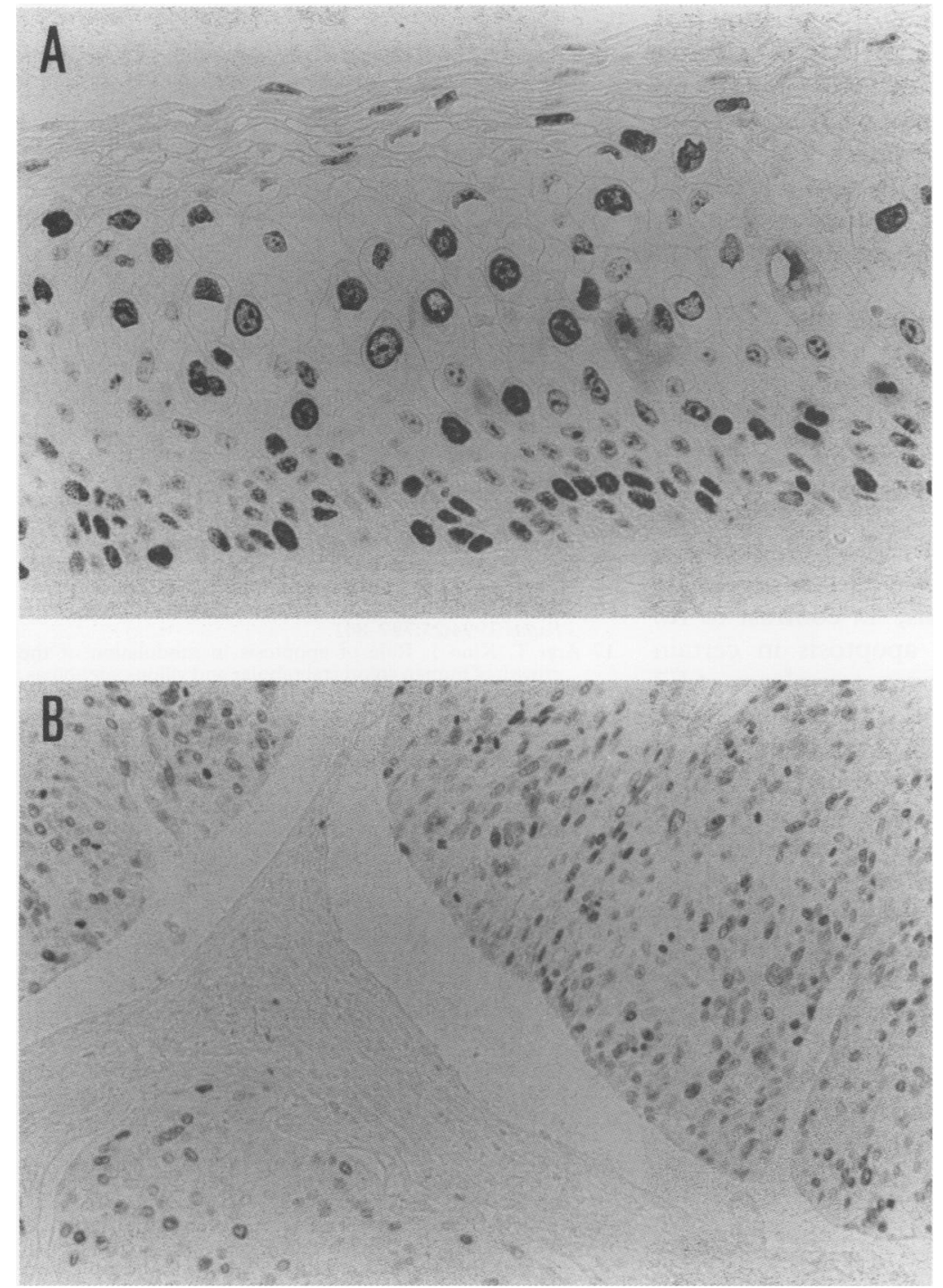

Figure 3 Ki-67 immunohistochemistry. (A) Note the strong Ki-67 immunoreactivity of koilocytotic cells as well as basal and parabasal cells in CIN II; $\times 345$. (B)

Heterogeneity of Ki-67 immunoreactivity in ISCC. The tumour nest on the right side shows a relatively high immunolabelling as compared with that on lower left side; $\times 173$.

Our study showed that apoptosis clearly increases with malignant grading in uterine cer- vical neoplasias. As a basic principle, CIN grading is positively correlated with abnormal maturation of basaloid cells. Morphological change of tumour cells in the process of development from CIN to MIC or ISCC may be considered as atypical differentiation as it has been asserted that one indication of squamous cell maturation is an increase in cytoplasm. ${ }^{14}$ In the HL-60, human promyelocytic leukaemia cell line, terminal differentiation induced by retinoic acid treatment serves to facilitate the apoptotic response. ${ }^{15} \mathrm{~A}$ positive correlation between frequency of apoptosis and histological malignant grading (loss of differentiation) has been noted in prostatic cancers ${ }^{16}$ and colonic tubular adenomas. ${ }^{17}$ It is therefore suggested that abnormal differentiating features may play an important role in the susceptibility of tumour cells to apoptosis in cervical neoplasias. In addition, our investigation revealed a statistically significant difference between MIC and ISCC, suggesting that the frequency of apoptosis may be linked with tumour progression. There have been similar findings in human gastric carcinomas. ${ }^{18}$

A close association between apoptotic and mitotic indices has been found in various human tumours. ${ }^{1617}$ In the present study, we used $\mathrm{Ki}-67$ immunohistochemistry to determine the cell proliferative activity instead of estimating the mitotic index. Earlier studies showed that $\mathrm{Ki}-67$ immunoreactivity can be detected in all phases of the cell cycle except $\mathrm{G}_{0 .}{ }^{1920}$ Results for this index are closely related to those for several prognostic indices in nonHodgkin lymphomas ${ }^{21}$ and breast carcinomas. ${ }^{22}$ However, Shepherd et $a l^{23}$ have reported that in colorectal carcinomas $\mathrm{Ki}-67$ labelling rates do not correlate with known prognostic indices such as tumour differentiation, Dukes' stage, or lymph node metastasis, suggesting that the proliferative status alone has no influence on the prognosis after surgical treatment. Our results also show no apparent relation between $\mathrm{Ki}-67 \mathrm{LI}$ and either A-LI or morphological malignant grading in
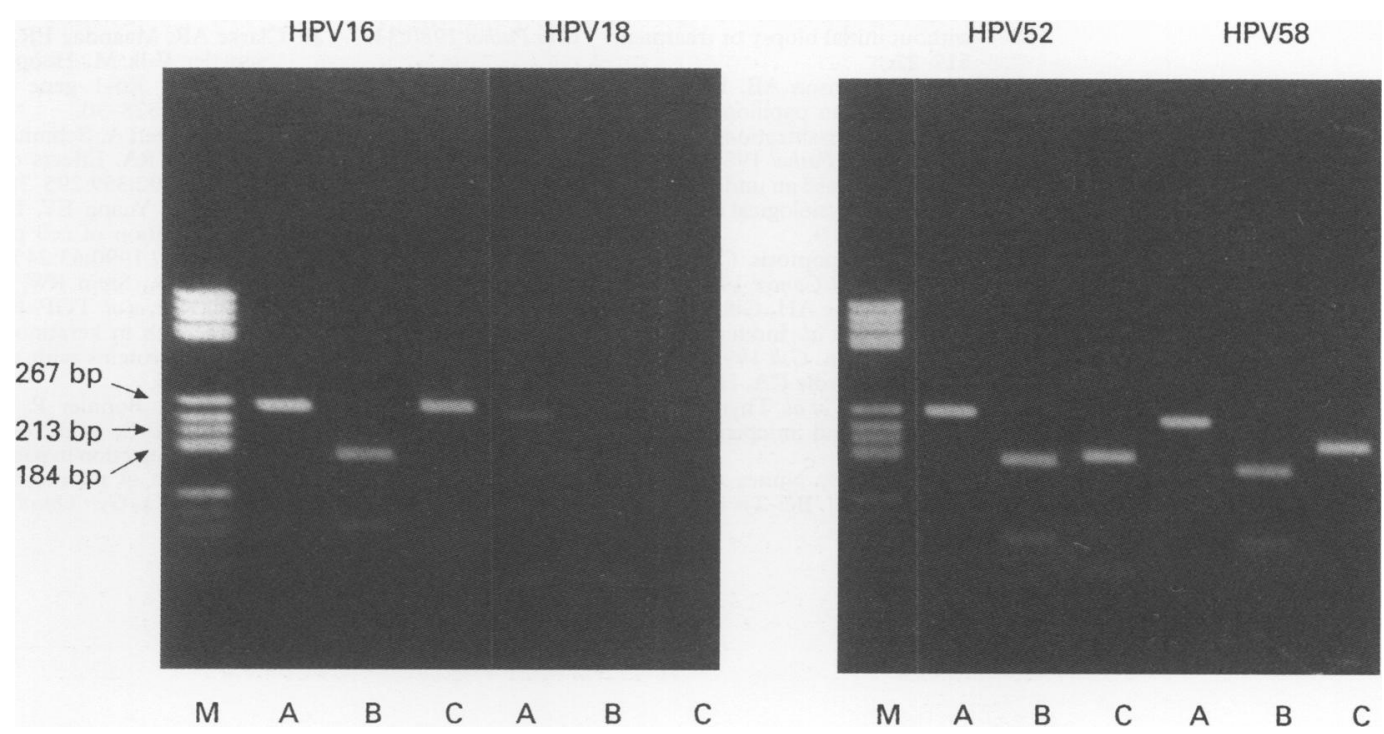

Figure 4 HPV types 16, 18, 52, and 58 demonstrated by PCR-RFLP assay: lane a, uncut; lane b, Dde I digestion; lane c, Rsa I digestion. $m$, molecular markers (DNA molecular weight markers $V$, Boehringer Mannheim/Yamanouchi). 
cervical neoplasias. This lack of correlation may be due to the marked variation in $\mathrm{Ki}-67$ positive cell distribution within individual tumours, or the detection of an extensive cell cycle phase by $\mathrm{Ki}-67$ immunohistochemistry. The fact that koilocytotic cells existing in upper layers in CIN II also occasionally reacted to $\mathrm{Ki}-67$ as well as the basaloid cells resulted in a high labelling index value.

Previous studies have shown that HPV can play a central role in the cervical tumorigenesis, ${ }^{24} 25$ and that the overall HPV prevalence in cervical carcinomas was $92.9 \%$ and ranged from $75 \%$ to $100 \%$ by country. ${ }^{26}$ The oncoproteins, E6 and E7, produced by HPV, are capable of binding to p53 and the retinoblastoma susceptibility gene product $R b$, respectively. ${ }^{2728}$ Wild-type p53 can accelerate the induction of apoptosis, ${ }^{7}$ in contrast to $\mathrm{Rb}$ itself which can inhibit apoptosis in certain circumstances. ${ }^{2930}$ Moreover, complexes of E7 and $\mathrm{Rb}$ are reported to release $\mathrm{Rb}$ mediated repression of c-myc $c^{3132}$ which stimulates apoptosis. In this context it is of interest that c$m y c$ expression has been observed in invasive cervical carcinomas, closely correlating with prognosis. ${ }^{33}$ These findings may indicate a complex linkage between HPV infection and apoptosis. In this study, no apparent correlation was found between presence of HPV-DNA and apoptosis, with the exception of the ISCC cases, suggesting that HPV itself is not directly involved in the apoptosis regulatory pathways in cervical neoplasias. This conclusion is supported by the finding of the same degree of positivity for HPV-DNA in CINs, MIC, and ISCC.

In conclusion, our study provides evidence for a close correlation between apoptosis and differentiation and progression of cervical tumour cells, independent of HPV infection.

This work was supported in part by the Parents' Association Grant of Kitasato University, School of Medicine.

1 Herrington CS. Human papillomaviruses and cervical neoplasia. II. Interaction of HPV with other factors. $\mathcal{F}$ Clin Pathol 1995;48:1-6.

2 Spriggs AI, Boddington MM. Progression and regression of cervical lesions: review of smears from women followed without initial biopsy or treatment. $\mathcal{F}$ Clin Pathol 1980;33: 517-22.

3 Brescia RJ, Jenson AB, Lancaster WD, Kurman RJ. The role of human papillomaviruses in the pathogenesis and
histologic classification of precancerous lesions of the histologic classification of precancero
cervix. Hum Pathol 1986;17:552-9.

4 Vaux DL. Toward an understanding of the molecular mechanisms of physiological cell death. Proc Natl Acad Sci USA 1993;90:786-9.

5 Wyllie AH. Apoptosis (The 1992 Frank Rose memorial lecture). Br f Cancer 1993;67:205-8.

6 Evan GI, Wyllie AH, Gilbert CS, Littlewood TD, Land H, Brooks $\mathrm{M}$, et al. Induction of apoptosis in fibroblasts by c-myc protein. Cell 1992;69:119-28.

7 Clarke AR, Purdie CA, Harrison DJ, Morris RG, Bird CC Hooper ML, et al. Thymocyte apoptosis induced by $\mathrm{p} 53$ dependent and independent pathways. Nature 1993;362: 849-52.

8 Hockenbery D, Nunez G, Milliman C, Schreiber RD, Korsmeyer SJ. Bcl-2 is an inner mitochondrial membrane protein that blocks programmed cell death. Nature 1990; 348:334-6.

9 Lowe SW, Ruley HE, Jacks T, Housman DE. p53-dependent apoptosis modulates the cytotoxicity of anticancer agents. Cell 1993;74:957-67.

10 Gavrieli Y, Sherman Y, Ben-Sasson SA. Identification of programmed cell death in situ via specific labeling of nuclear DNA fragmentation. $\mathcal{f}$ Cell Biol 1992;119:493501.

11 Richart RM. Cervical intraepithelial neoplasia. Pathol Annu 1973;8:301-28.

12 Coates PJ, d'Ardenne AJ, Khan G, Kangro HO, Slavin G. Simplified procedures for applying the polymerase chain reaction to routinely fixed paraffin wax sections. $f$ Clin reaction to routinely fithol $1991 ; 44: 115-8$.

13 Yoshikawa H, Kawana T, Kitagawa K, Mizuno M, Yoshikura $\mathrm{H}$, Iwamoto A. Detection and typing of multiple genital human papillomaviruses by DNA amplification with consensus primers. Fpn $\mathcal{F}$ Cancer Res 1991;82:524-31.

14 Ehrmann R L. Early stromal invasion. In: Ehrmann RL, ed. Benign to malignant progression in cervical squamous epithelium. New York: Igaku-shoin, 1994:116-42.

15 Martin SJ, Bradley JG, Cotter TG. HL-60 cells induced to differentiate towards neutrophils subsequently die via apoptosis. Clin Exp Immunol 1990;79:448-53.

16 Aihara M, Truong LD, Dunn JK, Wheeler TS, Scardino PT, Thompson TC. Frequency of apoptotic bodies positively correlates with Gleason grade in prostate cancer. Hum correlates with Gleason
Pathol 1994;25:797-801.

17 Arai T, Kino I. Role of apoptosis in modulation of the growth of human colorectal tubular and villous adenomas. f Pathol 1995;176:37-44.

18 Saegusa M, Takano Y, Wakabayashi T, Okayasu I. Apoptosis in gastric carcinomas and its association with cell proliferation and differentiation. fpn $\mathcal{f}$ Cancer Res, 1995;86: $743-8$.

19 Gerdes J, Schwab U, Lemke H, Stein H. Production of a mouse monoclonal antibody reactive with a human nuclear antigen associated

20 Gerdes J, Lemke H, Baisch H, Wacker HH, Schwab U, stein $\mathrm{H}$. Cell cycle analysis of a cell proliferation-associated human nuclear antigen defined by the $\mathrm{m}$ antibody $\mathrm{Ki}-67$. F Immunol $1984 ; 133: 1710-6$.

21 Hall PA, Richards MA, Gregory WM, d'Ardenne AJ, Lister TA, Stansfeld AG. The prognostic value of $\mathrm{Ki}-67 \mathrm{im}-$ munostaining in non-Hodgkin's lymphoma. $\mathcal{F}$ Pathol 1988; 154:223-35.

22 McGurrin JF, Doria MI, Dawson PJ, Karrison T, Stein HO, Franklin WA. Assessment of tumor cell kinetics by immunohistochemistry in carcinoma of breast. Cancer 1987;59:1744-50.

23 Shepherd NA, Richman PI, England J. Ki-67 derived proliferative activity in colorectal adenocarcinoma with progliferative activity in colorectal adenocarcinom

24 Wilczynski SP, Bergen S, Walker J, Liao S-Y, Pearlman LF. Human papillomaviruses and cervical cancer: analysis of histopathologic features associated with different viral type. Hum Pathol 1988;19:697-704.

25 Paquette RL, Lee YY, Wilczynski SP, Karmakar A, Kizaki M, Miller CW, et al. Mutations of p53 and human papillomavirus infection in cervical carcinoma. Cancer 1993, 72:1272-80.

26 Bosch FX, Manos MM, Munoz N, Sherman M, Jansen $\mathrm{AM}$, Peto J, et al. Prevalence of human papillomavirus in cervical cancer: a worldwide perspective. $\mathcal{F}$ Natl Cancer Inst 1995;87:796-802.

27 Dyson N, Howley PM, Munger K, Harlow E. The human papillomavirus-16 E7 oncoprotein is able to bind to the retinoblastoma gene product. Science 1989;243:934-7.

28 Werness BA, Levine AJ, Howley PM. Association of human papillomavirus types 16 and 18 E6 proteins with p53. Science 1990;248:76-9.

29 Clarke AR, Maandag ER, van Roon M, van der Lugt NM, van der Valk M, Hooper ML, et al. Requirement for a functional $\mathrm{Rb}-1$ gene in murine development. Nature 1992;359:328-30.

30 Jacks T, Fazeli A, Schmitt EM, Bronson RT, Goodell MA, Weinberg RA. Effects of an Rb mutation in the mouse. Weinberg RA. Effects of a
Nature 1992;359:295-300.

31 Moses HL, Yuang EY, Pietenpol JA. TGF $\beta$ stimulation and inhibition of cell proliferation: new mechanistic insights. Cell 1990;63:245-7.

32 Pietenpol JA, Stein RW, Moran E, Yaciuk P, Schlegel R, Lyons RM, et al. TGF- $\beta 1$ inhibition of c-myc transcription and growth in keratinocytes is abrogated by viral transforming proteins with pRB binding domains. Cell 1990; 61:777-85.

33 Devictor B, Bonnier P, Piana L, Andrac L, Lavaut M$\mathrm{N}$, Allasia $\mathrm{C}$, et al. c-myc protein and $\mathrm{Ki}-67$ antigen immunodetection in patients with uterine cervix neoplasia: correlation of microcytophotometric analysis and histological data. Gyn Oncol 1993;49:284-90. 